\title{
Faktor determinan yang mempengaruhi preferensi pengguna terhadap pakaian dan rumah tinggal
}

\author{
Auliya Maula Alqadrie \\ Institut Teknologi Bandung, Bandung, Indonesia, auilyaalqadrie@gmail.com \\ Laras Primasari \\ Institut Teknologi Bandung, Bandung, Indonesia, laras.primasari@gmail.com \\ Hanson E Kusuma \\ Institut Teknologi Bandung, Bandung, Indonesia, hekusuma@gmail.com
}

\begin{abstract}
Abstrak
Preferensi merupakan pilihan terhadap sesuatu objek yang mencerminkan persepsi dan sikap individu. Persepsi dan sikap ini cenderung konstan sehingga terdapat kemungkinan kemiripan dalam preferensi individu terhadap pakaian dan rumah rumah tinggal. Penelitian ini merupakan studi awal untuk mengeksplorasi hubungan persamaan antara fashion dan arsitektur dari sudut pandang preferensi pakaian dan rumah tinggal. Penelitian ini merupakan penelitian kualitatif yang bersifat eksploratif dengan pendekatan grounded theory. Pengumpulan data menggunakan kuesioner daring dengan metode non-random sampling. Data teks yang terkumpul dianalisis dengan analisis isi (open coding). Hasilnya telah mengungkap kemiripan berbagai faktor yang menjadi pertimbangan dalam memilih pakaian dan rumah tinggal. Hasil studi juga telah berhasil mengidentifikasi delapan kategori faktor, yaitu citra, kenyamanan, suasana hati, materialitas, kebersihan, ekonomi, kemudahan, dan fungsi, serta berbagai kata kunci baru yang mempengaruhi preferensi individu terhadap pakaian dan rumah tinggal.
\end{abstract}

Kata Kunci: fashion, pakaian, preferensi individu, rumah tinggal

\begin{abstract}
Preference is a choice of an object that reflects individual perceptions and attitudes. These perceptions and attitudes tend to be constant so that there is a possibility of similarities in individual clothing and housing preferences. This research is a preliminary study to explore the similarities between fashion and architecture from clothing and residential preferences. This research is qualitative exploratory research with a grounded theory approach-data collection using online questionnaires with a non-random sampling method. The collected text data were analyzed using content analysis (open coding). The results have revealed the similarities between the various factors that are considered in choosing clothes and housing. The study results have also identified eight-factor categories, namely image, comfort, mood, materiality, cleanliness, economy, convenience, and function, and various new keywords that affect individual preferences for clothing and housing.
\end{abstract}

Keywords: fashion, clothing, individual preferences, housing

Received: 2019-09-26 | Accepted: 2020-04-23 | DOI: 10.29080/eija.v6i1.684| Page: 11 - 22

EMARA: Indonesian Journal of Architecture

http://jurnalsaintek.uinsby.ac.id/index.php/EIJA

This article is open access distributed under the terms of the Creative Commons Attribution

ShareAlike 4.0 International License, which permits unrestricted use, distribution, and

reproduction in any medium provided the original work is properly cited. 


\section{Pendahuluan}

Terdapat persamaan perspektif antara fashion yang diwakili oleh pakaian dan disain arsitektur yang diwakili oleh rumah yang keduanya menjadi sebuah kebutuhan dasar bagi manusia (Miller, 2016). Baik fashion ataupun arsitektur merupakan sebuah pelindung (protect) dan pernaungan (shelter), selain juga sebagai ekspresi identitas (Miller, 2016). Crewe (2010) juga menyatakan dalam disain, fashion dan arsitektur memiliki relevansi yang sama dalam hal warna, pengalaman sensori, persisten, dan tampilan. Perancang busana (fashion designer) berkarya melalui siluet dan arsitek berkarya dalam volume dan keduanya merupakan sesuatu yang sama (Nicosia, 2014). Keduanya berkaitan dengan menghasilkan sebuah bentuk (forms) dan wujud (shapes) yang memiliki perbedaan ukuran dan skala. Fashion adalah pelindung (shield) badan manusia, sedangkan arsitektur merangkum kelipatannya (Miller, 2016).

Preferensi merupakan kecenderungan pilihan individu terhadap sesuatu objek, dimana pola preferensi individu akan mencerminkan persepsi dan sikap orang tersebut. yang cenderung sulit berubah (Lichtenstein \& Slovic, 2006). Kondisi tersebut memungkinkan munculnya kemiripan dalam preferensi seseorang terhadap pakaian dan rumah. Sudut pandang tersebut dapat dimanfaatkan bagi seorang arsitek saat mencari sebuah gagasan disain rumah berdasarkan preferensi berpakaian calon pengguna.

Sebuah rumah yang dirancang dapat merefleksikan preferensi calon pemilik rumah (Molin et al., 1996). Preferensi terkait tempat tinggal juga menjadi hal yang penting bagi pemerintah maupun pengembang agar pembangunan perumahan dapat tepat sasaran. Berbagai aspek yang muncul pada preferensi rumah diantaranya meliputi aspek aksesibilitas, lokasi, tipe dan disain bangunan, lingkungan, ketersediaan fasilitas, harga, kenyamanan, dan keamanan (Anindyajati et al., 2014; Nadiya, 2017; Tambunan, 2009).

Persepsi merupakan hal yang vital dalam fashion design dan garmen, dimana persepsi individu akan mempengaruhi berbagai rancangan produk pada berbagai tahapan dan level (Montagna, 2015). Pengguna dan disainer mewakili dua kelompok yang berbeda dalam proses perancangan sebuah produk. Mereka mewakili dua perbedaan sudut pandang, pengalaman hidup, latar belakang budaya, perbedaan aesthetics, pemahaman (understanding), apresiasi material, perbedaan utilitas dan lain lain (Montagna, 2015). Sudut pandang tersebut merupakan beberapa alasan subjektif yang memaksimalkan perbedaan persepsi terhadap proyek fashion dan semua perbedaan fase perkembangan (Montagna, 2015).

Dalam metodologi yang diadaptasi oleh Montagna (2015), sebuah fashion design memiliki beberapa atribut yang berbeda. Atribut tersebut dikelompokkan kepada tahapan saat merancang, seperti sebuah disain macro structure. Berbagai aspek yang mempengaruhi sebuah disain pakaian adalah gambaran (pictures), suasana (mood), gaya (style), pandangan (view), dan konsep yang biasa digabungkan menjadi imajiner kreatif (creative imaginary). Kemudian aspek selanjutnya adalah kebutuhan pengguna, bentuk (form), volume, material, aesthetic, finishing, dan warna. Aspek terakhir lebih mengenai lingkup disain yakni pola disain dan model (Montagna, 2015).

Elemen dan detil tertentu dalam arsitektur dan fashion cenderung menjadi 
ide dan inspirasi yang berguna di balik perancangan busana maupun disain bangunan. Hal ini didukung dengan kedua sifat fashion dan arsitektur yang terstruktur, terkait visual dan seni dalam penampilan. Keduanya juga merupakan karya tiga dimensi yang didefinisikan dalam bentuk (form) dan ruang (space)(Chinwendu, 2014).

Dalam proses disain, baik pakaian maupun rumah memiliki tahapan proses kreatifnya yang hampir sama. Hubungan antara fashion dan arsitektur telah lama dibahas, akan tetapi hubungan antara keduanya jarang dieksplorasi baik oleh disainer ataupun arsitek (Quinn, 2003). Penelitian ini merupakan studi awal untuk mengetahui faktor determinan dan hubungan antara preferensi seseorang terhadap pakaian dengan rumah tinggal.

\section{Metode}

Penelitian ini dilakukan secara kualitatif dengan pendekatan grounded theory yang bersifat eksploratif. Grounded theory merupakan pendekatan penelitian kualitatif yang menggali faktor-faktor yang menyusun fenomena dari perspektif subjek penelitian (Creswell, 2013). Data dikumpulkan dengan kuesioner daring yang di sebarkan dengan metode snowball sampling. Pertanyaan kuesioner bersifat terbuka (open-ended). Responden dapat memberikan jawaban dengan bebas sesuai dengan yang dirasakan dan dipikirkannya. Pertanyaan di dalam kuesioner dibagi menjadi dua kelompok bagian. Bagian pertama berisi pertanyaan tentang atribut responden. Sedangkan bagian ke dua berisi pertanyaan terbuka tentang pendapat responden berbagai faktor determinan yang menjadi pertimbangan responden saat memilih pakaian untuk digunakan sehari-hari dan pertimbangan responden dalam memilih rumah tinggal untuk dihuni atau beraktivitas sehari-hari.
Data yang terkumpul dari pertanyaan terbuka ini berupa data teks yang selanjutnya akan dianalisis dengan analisis isi (content analysis) yang diikuti dengan open coding. Open coding merupakan proses pengkategorian data berdasarkan kata kunci yang berasal dari jawaban responden (Creswell, 2013).

\section{Hasil dan Pembahasan}

Berbagai kata kunci dari jawaban responden terhadap pertanyaan terbuka diidentifikasi, seperti pada contoh kutipan kalimat jawaban berikut:

Preferensi pakaian: "Bahan mudah menyerap keringat, warna bagus dan model yang tidak aneh-aneh (simpel)"

Preferensi rumah: "Tidak terlalu luas, minimalis karena simple"

Berdasarkan contoh kutipan jawaban responden tersebut diidentifikasi beberapa kata kunci, diantaranya kunci "termal", "warna", "disain" dan "style" pada bagian preferensi pakaian dan kata kunci "ukuran" dan "style" pada bagian preferensi rumah tinggal. Temuan dari berbagai kata kunci tersebut kemudian dikelompokkan menjadi kategori. Dari proses pengkategorian ditemukan 12 kategori terkait beragam aspek preferensi pakaian sehari-hari dan rumah tinggal. Pada Appendix 1 terdapat delapan persamaan kategori preferensi pakaian dan rumah yang teridentifikasi.

Di antara delapan kategori tersebut, kategori yang paling dominan adalah citra dengan frekuensi 211 (36,8\%) dan kenyamanan 202 (35,2\%). Sedangkan kategori fungsi dan ekonomi menempati peringkat terendah dengan nilai 17 (3\%) dan 25 (4,4\%), secara berurutan (gambar 1). Dari hasil analisis diketahui juga bahwa terdapat perbedaan perbedaan frekuensi antara kategori preferensi pakaian dan rumah tinggal saat dibandingkan satu sama lain (gambar 2) 


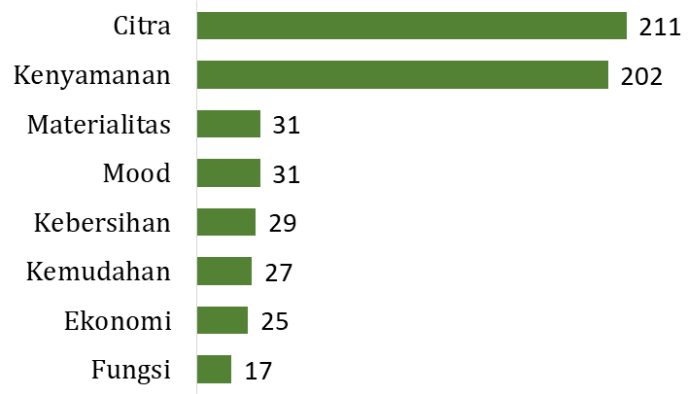

Gambar 1. Persamaan kategori/faktor preferensi pakaian sehari-hari dan rumah tinggal (sumber: analisis peneliti, 2008)

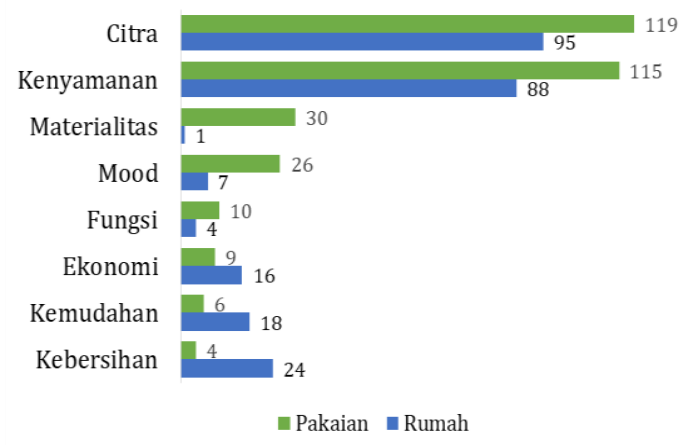

Gambar 2. Perbandingan kategori/faktor preferensi pakaian sehari-hari dan rumah tinggal (sumber: analisis peneliti, 2008)

\section{Citra}

Citra menjadi faktor yang memiliki frekuensi paling dominan pada preferensi pakaian dan rumah. Citra didefinisikan sebagai suatu rupa; gambar; gambaran (KBBI, 2016). Pada kategori ini terdapat kata kunci yang menyusun kategori citra yaitu visual, estetika, warna, disain, style, kualitas, dan ukuran. Berikut contoh komentar salah satu responden yang mencerminkan aspek citra dari rumah tinggal.

"Tidak terlalu luas, minimalis karena

$$
\text { simpel" }
$$

Dari kalimat "Tidak terlalu luas" dapat diambil kata kunci ukuran. Sedangkan "minimalis" termasuk dalam kata kunci style. Kata minimalis di sini dapat diartikan sebagai minimalism yang menurut Merriam-Webster (2018) diartikan sebagai sebuah langgam/gaya (style) atau teknik (dalam dunia musik, literatur, dan disain) yang memiliki karakter kesederhanaan dalam penampilan. Komentar responden lainnya yang sama tentang preferensi pakaian sebagai contoh berikut:

"Bahan mudah menyerap keringat, warna bagus dan model yang tidak aneh-aneh

$$
\text { (simpel)" }
$$

Pada respon kutipan tersebut dapat diambil beberapa kata kunci diantaranya "warna yang bagus" sebagai warna, "model" sebagai disain dan "model yang tidak aneh-aneh (simpel)" dapat diartikan sebagai kesederhanaan yang identik pada jenis style. Untuk memahami kehadiran konsep citra yang hadir antara fashion dan arsitektur atau sebaliknya, maka analogikan sebuah bangunan sebagai lipatan gaun, dan gaun "arsitektural" sebagai ruang besar yang dipenuhi ruangan dan individu (Farahat, 2014).

\section{Kenyamanan}

Kenyamanan merupakan kategori ke dua dari preferensi pakaian dan rumah yang dominan. Kategori ini berhubungan langsung kepada kata kunci kenyamanan, termal, pencahayaan dan ketenangan. Berikut contoh komentar salah satu responden yang mencerminkan aspek kenyamanan dari rumah tinggal.

"Lokasinya strategis, model rumahnya mengikuti tren saat ini, ada taman yang luas, berada di kawasan yang aman, tempatnya dingin."

Pada respon tersebut dapat diambil 1 kata kunci yang mencerminkan aspek kenyamanan yaitu "tempatnya dingin" yang dapat dikategorikan kepada kondisi termal.

"Enak dipakai tidak panas, mengikuti tren saat ini, tidak sempit."

Sedangkan pada komentar terkait preferensi pakaian diatas mengindikasikan dua kata kunci yang berkaitan dengan kenyamanan. Kalimat "Enak dipakai tidak panas" dapat dikategorikan menjadi kenyamanan dan termal. Baik pada rumah tinggal ataupun 
pakaian, persoalan kenyamanan merupakan persoalan yang esensial bagi penggunanya (Clark, 2012).

\section{Mood}

Mood adalah adalah keadaan sadar pikiran atau emosi dominan (Merriam-Webster, 2018) yang padanan dalam istilah lokal dapat diasosiasikan dengan suasana. Beragam kata kunci termasuk dalam kategori ini diantaranya adalah suasana, suasana dan mood. Salah satu komentar responden terkait dengan mood saat mengenakan pakaian diantaranya sebagai berikut:

"Acara yang dihadiri, bertemu/pergi bersama siapa, keduanya menurut saya faktor yang penting dalam memilih pakaian sehari-hari karena dengan tahu acara dan orang yang terlibat dalam sebuah acara, selain akan terlihat serasi dengan acara tersebut tetapi juga membuat kita nyaman dengan diri sendiri tanpa merasa tidak pantas dan nyaman saat komunikasi dengan orang lain. Selain itu, yang terpenting juga kenyamanan kita terhadap pakaiannya."

Respon mengenai kategori mood dapat dirujuk dari potongan kalimat "Acara yang dihadiri" termasuk dalam aspek suasana. Setiap acara dan aktivitas berbeda dianggap memiliki suasana yang berbeda pula. Suasana akan berpengaruh kepada preferensi pilihan pakaian individu atau yang lazim dikenal dengan dresscode pakaian. Sedangkan berikut ini pernyataan responden terkait persoalan mood di rumah tinggal:

"Terlihat luas dan rapi, jadi walaupun kecil tapi dengan penataan yang bagus itu bagus. Susunan ruangan terarah dan jelas, misalnya perletakan ruang keluarga yang diatur sedemikian rupa agar tidak dilewati orang-orang, jadi suatu ruangan tidak terganggu fungsinya dengan fungsi kegiatan lainnya. Ada taman kecil di dekat rumah juga sesuatu yang menyenangkan, saya sendiri saat melihat tanaman saat sedang pusing membuat saya sedikit segar. Ruang tidur dengan kasur empuk dan suasana sejuk menurut saya, penting karena tidur merupakan salah satu faktor yang sangat berpengaruhi terhadap kegiatan saya di esok harinya."

Pada kalimat tersebut beberapa kata menandakan kecenderungan pada faktor suasana. Deskripsi ruang menggunakan kata "terlihat" ataupun deskripsi keadaan kamar menggambarkan suasana yang diinginkan oleh responden. Sehingga komentar ini teridentifikasi mengandung unsur kata kunci suasana. Pada gambar 2 jelas menunjukkan frekuensi mood pada preferensi pakaian lebih tinggi daripada preferensi rumah tinggal. Hal ini menunjukkan kecenderungan suasana lebih dipertimbangkan dalam memilih pakaian daripada rumah tinggal. Hal ini diperkuat oleh penelitian Sugiarto (2019) yang menyatakan faktor determinan preferensi publik dalam memilih hunian lebih cenderung kepada aspek aksesibilitas serta kelengkapan sarana dan prasarana.

\section{Materialitas}

Hasil analisis konten menunjukkan materialitas tidak menjadi faktor dominan yang dipertimbangkan dalam memilih rumah tinggal, dimana hanya satu responden yang menyebutkan materialitas. Berikut ini contoh pernyataan responden tentang materialitas pada preferensi rumah.

"Rumah yang bisa melindungi penghuninya dari panas matahari dan dari hujan. Bukaan yang banyak dan efektif pada rumah dapat memudahkan sirkulasi udara di dalam ruangan sehingga kualitas udara di dalam rumah baik, tidak membuat gerah. Material yang digunakan tidak mudah menyimpan panas, karena dapat membuat ruangan di dalamnya menjadi panas dan tidak nyaman." 
Pada kalimat terakhir responden menunjukkan penekanan preferensi tentang pentingnya isu jenis material pada rumah untuk mencapai kebutuhan atau tujuan tertentu penggunanya. Kemudian, pada preferensi pakaian responden juga menyatakan sebagaimana berikut ini:

"Pakaian yang bahannya 1.tidak menerawang 2.mudah menyerap keringat 3.materialnya tidak kaku. Karena dengan begitu akan lebih nyaman dan mudah beraktifitas."

Pada komentar tersebut susunan kalimat pembuka "pakaian yang bahannya" menunjukan penekanan pada karakteristik material sebagai pertimbangan utama responden dalam memilih pakaiannya.

\section{Kebersihan}

Kebersihan merupakan faktor ke-lima yang mempengaruhi preferensi pakaian dan rumah tinggal. Adapun contoh pernyataan responden mengenai kebersihan saat memilih pakaian dan rumah sebagaimana berikut:

"Kenyamanan, karena saya lebih suka memakai pakaian yang membuat saya nyaman. Kelayakan, karena dengan baju yang layak dipakai maka akan timbul rasa nyaman untuk digunakan. Simpel, karena saya lebih suka menggunakan pakaian yang mudah dipakai. Bersih, dengan pakaian yang bersih maka saya akan menikmati dalam menggunakan pakaian tersebut. Bahan yang sejuk, dengan pakaian yang tidak panas maka akan membuat saya menjadi nyaman."

Pada kalimat tersebut, kata "Bersih" dapat dikelompokkan ke dalam kategori kebersihan. Alasan yang diungkap untuk mendukung kata kunci adalah kepuasan pengguna saat menggunakan pakaian. Kemudian pada preferensi rumah dinyatakan sebagaimana berikut ini:

"Kenyamanan, karena dengan rumah yg nyaman maka akan membuat kita selalu ingin berada di rumah. Layak, dengan rumah yang layak digunakan maka keamanan dan kenyamanan dalam menggunakannya akan terjamin. Bersih, dengan rumah yang bersih maka saya tidak akan bosan untuk berada di rumah. Sejuk, dengan rumah yang sejuk dan sirkulasi udara yang bagus maka saya akan betah untuk berada di rumah."

Pada komentar tersebut, aspek kebersihan juga ditemukan pada bagian kalimat ke-tiga dari responden. Hubungan yang penting terkait kebersihan dengan perasaan yang muncul saat menempati rumah juga disiratkan oleh jawaban responden. Hal ini sejalan dengan hasil penelitian sebelumnya yang menyatakan bahwa kebersihan sebagai bagian dari unsur kenyamanan lingkungan hunian yang menjadi faktor mendasar bagi individu dalam memilih lingkungan hunian (Syafrina et al., 2018).

\section{Ekonomi}

Meskipun tidak menjadi faktor yang paling dominan, akan tetapi ekonomi tetap menjadi faktor yang dipertimbangkan dalam memilih pakaian dan rumah tinggal. Berikut contoh komentar dari responden mengenai faktor ekonomi pada pakaian dan rumah tinggal.

"Model dan harga pakaian."

"Suasana dan harga rumah."

Hal ini sejalan dengan berbagai penelitian yang menunjukkan faktor harga dan pembiayaan menjadi aspek preferensi individu dalam memilih dan memutuskan perumahan bagi dirinya (Nugroho et al., 2018; Wisnupraba, 2015)

\section{Kemudahan}

Pada faktor kemudahan teridentifikasi dua kata kunci yaitu praktis dan akses. Berikut contoh komentar responden terkait kemudahan dalam preferensi pakaian

"Nyaman dan mudah dipakai, pakaiannya rapi (sudah disetrika), dan model/gaya/style dari pakaian tersebut." 
Penyataan terkait "mudah dipakai" dikategorikan pada aspek praktis. Sedangkan untuk preferensi rumah tinggal dinyatakan oleh responden sebagaimana contoh pernyataan responden berikut ini.

"Bersih, luasnya pas dengan yang diinginkan atau dibutuhkan, lingkungannya baik, akses dari dan menuju ke rumah itu mudah, model rumah tersebut, dan harga rumahnya terjangkau."

Pada bagian kalimat "akses dari dan menuju rumah" disebutkan secara langsung poin akses. Aspek di sini dimaksudkan kepada kemudahan untuk mencapai titik-titik lokasi aktivitas penggunanya. Hal ini sejalan dengan penelitian Asteriani (2011) serta Rezita \& Rahayu (2017) yang menempatkan aspek aksesibilitas sebagai salah satu unsur yang mempengaruhi individu dalam memilih lokasi huniannya.

\section{Fungsi}

Fungsi merupakan prioritas terakhir dalam pemilihan pakaian dan rumah. Berikut ini merupakan pernyataan responden mengenai fungsi rumah yang diinginkan.

"Kurang lebih sama dengan ketika memilih pakaian. Warna, bentuk dan disain tidak terlalu dipermasalahkan, yang penting nyaman dan bagian rumah berfungsi dengan baik. Yang menjadi poin utama bagi saya adalah ukuran rumah dan lingkungan di sekitar rumah itu sendiri. Saya lebih memilih rumah dengan ukuran sedang, tidak terlalu besar dan tidak terlalu kecil juga tapi masih bisa dikembangkan, tipe 45 kalau anak-anak masih kecil dan maksimal tipe 100 ketika anak-anak sudah besar. Dengan kata lain, saya lebih memilih rumah yang bisa bertumbuh. Poin selanjutnya adalah lingkungan sekitar rumah. Saya akan lebih memilih rumah yang berada di lingkungan bertetangga yang baik dan religius. Selain itu, rumah di lingkungan yang aksesnya mudah ke masjid, rumah sakit, pasar dan tempat makan lebih saya sukai dan akan menjadi poin utama pertimbangan dalam memilih rumah."

Pada pernyataan "yang penting nyaman dan bagian rumah berfungsi dengan baik" disebutkan secara langsung aspek fungsi. Selanjutnya contoh pernyataan responden tentang fungsi pakaian seperti tercantum berikut ini:

"1.Nyaman, wajib nyaman 2.Nyaman, harus nyaman 3.Fungsional, mendukung aktivitas yang sedang dilakukan 4.Ekonomis, worth to pay, tidak harus membayar lebih mahal untuk hal-hal yang tidak mendukung poin 1-3."

Pada pernyataan "Fungsional, mendukung aktivitas yang sedang dilakukan", dengan jelas responden menyebutkan kata kunci untuk aspek fungsi. Hal ini selaras dengan penelitian Tambunan (2009) yang menyatakan bahwa salah satu aspek yang dipertimbangkan oleh individu dalam memilih huniannya adalah faktor fungsi, yang dapat memenuhi kebutuhan penggunanya dalam aktivitas harian.

Selain delapan katagori yang telah dibahas, terdapat juga katagori lain yang dipertimbangkan dalam memilih pakaian tetapi tidak menjadi pertimbangan dalam memilih rumah, ataupun sebaliknya. Pada pakaian, terdapat kategori privasi yang berdasar pada kata kunci preferensi responden untuk menutup aurat. Sedangkan pada preferensi rumah, terdapat tiga kategori yang hanya dipertimbangkan pada preferensi rumah yaitu infrastruktur, lingkungan, dan keamanan. Kategori infrastruktur tersusun dari beberapa kata kunci seperti permasalahan air, listrik, ketersediaan fasilitas sosial, fasilitas umum, infrastruktur dan pembuangan sampah. Kata kunci yang terkait pada kategori lingkungan adalah lingkungan (keadaan lingkungan tetangganya, lingkungan 
sekitar dan lain-lain) serta lokasi. Sedangkan kategori keamanan dan keselamatan mewakili aspek keamanan dari tindakan kriminalitas maupun terkait kekuatan bangunan.

Dari total jumlah 125 responden diperoleh frekuensi persamaan komentar sebesar 81 orang $(64,8 \%)$. Berdasarkan kuantitas persamaan yang lebih besar dapat dijadikan dasar adanya persamaan aspek preferensi pakaian dan rumah tinggal bagi responden. Pernyataan persamaan ini juga didukung oleh sifat persepsi seseorang yang mencerminkan sikap yang cenderung konstan (Sueca et al., 2001). Semua kata kunci mengenai preferensi pakaian berkesinambungan dengan teori Montagna (2015) yakni aspek picture, view, suasana (mood), style, bentuk, volume, material, estetika, warna, dan kebutuhan. Pada teori tersebut dapat ditemukan berbagai aspek yang lebih detail dan rinci daripada yang dihasilkan pada penelitian ini seperti, aspek visual yang terbagi menjadi picture dan view.

Berbagai aspek yang muncul pada preferensi rumah juga memiliki persamaan dengan teori yang dinyatakan beberapa peneliti sebelumnya (lihat Appendix 2). Preferensi terkait perumahan meliputi aspek aksesibilitas, lokasi, tipe dan disain bangunan, lingkungan, ketersediaan fasilitas, harga, kenyamanan, dan keamanan (Anindyajati et al., 2014; Dokmeci et al., 1996; Nadiya, 2017; Tambunan, 2009). Pada berbagai penelitian tersebut terlihat bahwa terdapat sejumlah kata kunci preferensi rumah tinggal yang tidak disebutkan pada penelitian sebelumnya, misalnya visual, estetika, kualitas, suasana, kebersihan dan kekuatan bangunan. Hasil kajian telah memberikan wacana tentang keterkaitan antara fashion dan arsitektur yang dapat dijadikan pijakan awal untuk mengungkap lebih dalam lagi hubungan preferensi individu terhadap pakaian dan rumah tinggal. Korelasi antara ke duanya dapat membantu seorang arsitek dalam mengeksplorasi ide, gagasan dan kreativitas rancangannya sehingga menghasilkan rancangan hunian yang sesuai dengan keinginan pengguna berdasarkan preferensi pakaian kliennya.

\section{Kesimpulan}

Terdapat delapan faktor yang berturutturut menjadi determinan terkait preferensi pengguna terhadap pakaian dan rumah tinggal yakni citra, kenyamanan, mood, materialitas, kebersihan, ekonomi, kemudahan, dan fungsi. Dari delapan faktor determinan tersebut, hasil kajian juga berhasil mengidentifikasi sejumlah kata kunci baru yang mempengaruhi preferensi pengguna terhadap pakaian dan rumah tinggal. Akan tetapi penelitian ini memiliki keterbatasan terkait metode pengumpulan data yang masih menggunakan sistem non-random sampling, sehingga untuk meningkatkan realibilitas diperlukan penelitian sejenis yang dapat mengklarifikasi temuan penelitian ini.

\section{Pernyataan Pendanaan}

Dengan ini para penulis menyatakan bahwa penelitian ini bebas dari konflik kepentingan dengan pihak manapun dan melalui pembiayaan mandiri.

\section{Ucapan Terimakasih}

Para penulis mengucapkan terimakasih kepada Institut Teknologi Bandung dan semua pihak yang telah mendukung terlaksananya penelitian ini.

\section{Referensi}

Anindyajati, D. J., Soemarno, I., \& Soemardiono, B. (2014). Preferensi Keluarga Muda Dalam Memilih Rumah Tinggal Di Surabaya Berdasarkan Atribut Fisik Dan Infrastruktur Perumahan Publikasi MMT-ITS. Prosiding Seminar Nasional Manajemen 
Teknologi $\quad X X, \quad \mathrm{~B}-18-1-\mathrm{B}-18-8$. https://mmt.its.ac.id/publikasi/pre ferensi-keluarga-muda-dalammemilih-rumah-tinggal-disurabaya-berdasarkan-atribut-fisikdan-infrastruktur-perumahan/

Asteriani, F. (2011). Preferensi penghuni perumahan di kota pekanbaru dalam menentukan lokasi perumahan. Jurnal Ekonomi Pembangunan, 12(1), 77-91. http://publikasiilmiah.ums.ac.id/ha ndle/11617/1309

Chinwendu, A. (2014). Architecture + Fashion: A study of the connection between both worlds [Dissertation, Nottingham Trent University]. https://www.academia.edu/15271 328/Architecture_Fashion_A_study_ of_the_connection_between_both_w orlds

Clark, G. (2012). Beyond Codified Comfort: Building Design and Performance. Environment Design Guide, 1-8. JSTOR. https://doi.org/10.2307/26151913

Creswell, J. W. (2013). Qualitative Inquiry and Research Design: Choosing Among Five Approaches (Third Edition). SAGE.

Crewe, L. (2010). Wear:Where? The Convergent Geographies of Architecture and Fashion: Environment and Planning A, 42(9), 2093-2108. https://doi.org/10.1068/a42254

Dokmeci, V., Berkoz, L., Levent, H., Yurekli, H., \& Cagdas, G. (1996). Residential preferences in Istanbul. Habitat International, 20(2), 241-251. https://doi.org/10.1016/01973975(95)00060-7

Farahat, B. I. (2014). The interrelationship between fashion and architecture. Al-Azhar University Engineering Journal, 9(6), 1-17.
KBBI. (2016). Citra. In KBBI Daring. Badan Pengembangan dan Pembinaan Bahasa, Kementerian Pendidikan dan Kebudayaan Republik Indonesia.

https://kbbi.kemdikbud.go.id/entri /Citra

Lichtenstein, S., \& Slovic, P. (2006). The Construction of Preference. Cambridge University Press.

Merriam-Webster. (2018). MerriamWebster's Collegiate Thesaurus (2nd Edition). Merriam-Webster, Incorporated.

Miller, M. (2016). Fashion \& Architecture [Thesis, University of Cincinnati]. https://etd.ohiolink.edu/pg_10?0:: NO:10:P10_ACCESSION_NUM:ucin1 459439271

Molin, E., Oppewal, H., \& Timmermans, H. (1996). Predicting consumer response to new housing: A stated choice experiment. Netherlands Journal of Housing and the Built Environment, 11(3), 297-311. https://doi.org/10.1007/BF024965 93

Montagna, G. (2015). Multi-dimensional Consumers: Fashion and Human Factors. Procedia Manufacturing, 3, 6550-6556.

https://doi.org/10.1016/j.promfg.2 015.07.954

Nadiya, E. (2017). Studi preferensi Generasi y dalam memilih hunian di Jakarta Barat. Jurnal Muara Ilmu Ekonomi dan Bisnis, 1(1), 145-152. https://doi.org/10.24912/jmieb.v1 i1.417

Nicosia, M. (2014). When fashion meets architecture [Interview]. https://www.dazeddigital.com/fas hion/article/22652/1/whenfashion-meets-architecture Nugroho, S., Djunaedi, A., \& Iskandar, D. A. (2018). Preferensi Pemilihan 
Perumahan di Pinggiran Kota Surakarta Berdasarkan Motivasi Pembelian Rumah. Jurnal Tata Kota Dan Daerah Universitas Brawijaya, 10(1), 11-24. https://tatakota.ub.ac.id/index.php /tatakota/article/view/251/207

Quinn, B. (2003). The Fashion of Architecture. Bloomsbury Academic.

Rezita, A., \& Rahayu, S. (2017). Faktorfaktor pemilihan lokasi hunian perumahan di Kecamatan Ungaran Barat. Teknik PWK (Perencanaan Wilayah Kota), 6(3), 143-152. https://ejournal3.undip.ac.id/index .php/pwk/article/view/18053

Sueca, N. P., Primayatna, I. B. G., S, K. M., Nada, W., \& Wastika, D. N. (2001). Faktor-faktor determinan pengetahuan dan persepsi masyarakat tentang bangunan berlanggam bali. DIMENSI: Journal of Architecture and Built Environment, 29(2), 157-164. https://doi.org/10.9744/dimensi.2 9.2.

Sugiarto, S. (2019). Determinan preferensi publik dalam pemilihan lokasi perumahan terjangkau bersubsidi di kota Banda Aceh. Teras Jurnal Jurnal Teknik Sipil, 9(1), 71-82. https://doi.org/10.29103/tj.v9i1.1 88
Syafrina, A., Tampubolon, A. C., Suhendri, S., Hasriyanti, N., \& Kusuma, H. E. (2018). Preferensi Masyarakat tentang Lingkungan Perumahan yang Ingin Ditinggali. RUAS (Review of Urbanism and Architectural Studies), 16(1), 32-45. https://ruas.ub.ac.id/index.php/ru as/article/view/243

Tambunan, D. B. (2009). Atribut Yang Menjadi Pertimbangan Konsumen Dalam Membeli ProdUK Perumahan Penelitian Dan Analisis Conjoint. International Research Journal of Business Studies, 2(2), 141-153. https://doi.org/10.21632/irjbs.2.2. 37

Wisnupraba, M. (2015). Analisa faktorfaktor yang dipertimbangkan konsumen dalam pembelian unit rumah di cluster $\mathrm{x}$. Prosiding Seminar Nasional Manajemen Teknologi XXII, 10.

\section{Kontribusi Penulis}

Auliya Maula Alqadrie berkontribusi dalam konseptualisasi, pengumpulan data dan investigasi dan menyusun draft artikel dan editing.

Laras Primasari berkontribusi dalam pengumpulan data, analisis data, dan penyusunan draft artikel dan visualisasi data Hanson E Kusuma berkontribusi dalam metodologi, supervisi penelitian, validasi dan melakukan penelaahan artikel 
Appendix 1. Hasil open coding preferensi pakaian sehari-hari dan rumah tinggal

\begin{tabular}{|c|c|c|c|c|}
\hline Kategori & Kata kunci pakaian & $(f)$ & Kata kunci rumah & $(f)$ \\
\hline \multirow{11}{*}{ Citra (214) } & Visual & 10 & visual & 6 \\
\hline & Estetika & 4 & estetika & 1 \\
\hline & Warna & 32 & warna & 1 \\
\hline & Disain & 28 & disain & 19 \\
\hline & Style & 27 & style & 8 \\
\hline & kualitas & 5 & kualitas & 2 \\
\hline & ukuran & 9 & ukuran & 21 \\
\hline & ketebalan & 1 & interior & 5 \\
\hline & & & orientasi & 2 \\
\hline & & & area outdoor & 13 \\
\hline & & & tata ruang & 17 \\
\hline \multirow{3}{*}{ Mood (32) } & Suasana & 8 & Suasana & 6 \\
\hline & Occasion & 13 & & \\
\hline & Mood & 4 & & \\
\hline Privasi (12) & menutup aurat & 12 & & \\
\hline Materialitas (31) & material & 30 & material & 1 \\
\hline \multirow{4}{*}{$\begin{array}{l}\text { Kenyamanan } \\
\text { (203) }\end{array}$} & comfort & 85 & comfort & 42 \\
\hline & termal & 29 & penghawaan & 23 \\
\hline & & & pencahayaan & 13 \\
\hline & & & ketenangan & 10 \\
\hline Kemudahan (27) & Praktis & 6 & akses & 21 \\
\hline Ekonomi (25) & Harga & 9 & harga & 16 \\
\hline Fungsi (15) & Fungsi & 12 & fungsi & 5 \\
\hline Kebersihan (29) & kebersihan & 4 & kebersihan & 25 \\
\hline \multirow{6}{*}{ Infrastruktur (42) } & & & air/sumber air/saluran & 16 \\
\hline & & & listrik & 5 \\
\hline & & & fasum & 8 \\
\hline & & & fasos & 8 \\
\hline & & & infrastruktur & 4 \\
\hline & & & pembuangan sampah & 1 \\
\hline \multirow{2}{*}{ Lingkungan (7) } & & & Lokasi & 40 \\
\hline & & & lingkungan & 39 \\
\hline Keamanan \& & & & keamanan & 28 \\
\hline Keselamatan (29) & & & kekuatan bangunan & 1 \\
\hline
\end{tabular}


Appendix 2. Perbandingan antara Teori dan Hasil Penelitian Mengenai Preferensi Pakaian Sehari-hari dan Rumah Tinggal

\begin{tabular}{|c|c|c|c|}
\hline \multirow{2}{*}{$\begin{array}{l}\text { Preferensi rumah tinggal } \\
\text { pada penelitian } \\
\text { terdahulu (Anindyajati et al., } \\
\text { 2014; Dokmeci et al., 1996; } \\
\text { Nadiya, 2017; Tambunan, 2009) }\end{array}$} & \multirow{2}{*}{$\begin{array}{l}\text { Preferensi } \\
\text { Pakaian } \\
\text { menurut } \\
\text { Montagna } \\
\text { (2015) } \\
\end{array}$} & \multicolumn{2}{|c|}{ Preferensi pada penelitian ini } \\
\hline & & Pakaian & Rumah \\
\hline & $\begin{array}{l}\text { - Pictures, } \\
\text { - view }\end{array}$ & Visual & Visual \\
\hline & Estetika & Estetika & Estetika \\
\hline \multirow[t]{8}{*}{ Tipe dan disain bangunan } & Warna & Warna & Warna \\
\hline & Bentuk & Disain & $\begin{array}{l}\text { - Disain } \\
\text { - Ukuran } \\
\text { - interior }\end{array}$ \\
\hline & Style & Style & $\begin{array}{l}\text { - Style } \\
\text { - Orientasi } \\
\text { - taman/halaman, } \\
\text { - tata ruang } \\
\end{array}$ \\
\hline & & \multicolumn{2}{|l|}{ Menutup aurat } \\
\hline & Finishing & Kualitas & Kualitas \\
\hline & Volume & $\begin{array}{l}\text { - Ukuran } \\
\text { - ketebalan } \\
\end{array}$ & \\
\hline & Mood & $\begin{array}{l}\text { - Suasana/occasion } \\
\text { - mood }\end{array}$ & Suasana \\
\hline & Material & Material & Material \\
\hline Kenyamanan & & $\begin{array}{l}\text { - Kenyamanan } \\
\text { - Termal }\end{array}$ & $\begin{array}{l}\text { - Kenyamanan } \\
\text { - Termal/penghawaan } \\
\text { - Pencahayaan } \\
\text { - Ketenangan } \\
\end{array}$ \\
\hline Aksesibilitas & & Praktis & Akses \\
\hline Harga & & Harga & Harga \\
\hline & $\begin{array}{l}\text { Kebutuhan } \\
\text { pengguna }\end{array}$ & Fungsi & Fungsi \\
\hline & & Kebersihan & Kebersihan \\
\hline Ketersediaan fasilitas & & & $\begin{array}{l}\text { - Air/sumber } \\
\text { air/saluran Listrik } \\
\text { - Fasum } \\
\text { - Fasos } \\
\text { - Infrastruktur } \\
\text { - Pembuangan } \\
\text { sampah }\end{array}$ \\
\hline Lokasi & & & Lokasi \\
\hline Lingkungan & & & Lingkungan \\
\hline Keamanan & & & $\begin{array}{l}\text { - Keamanan } \\
\text { - Kekuatan bangunan }\end{array}$ \\
\hline
\end{tabular}

